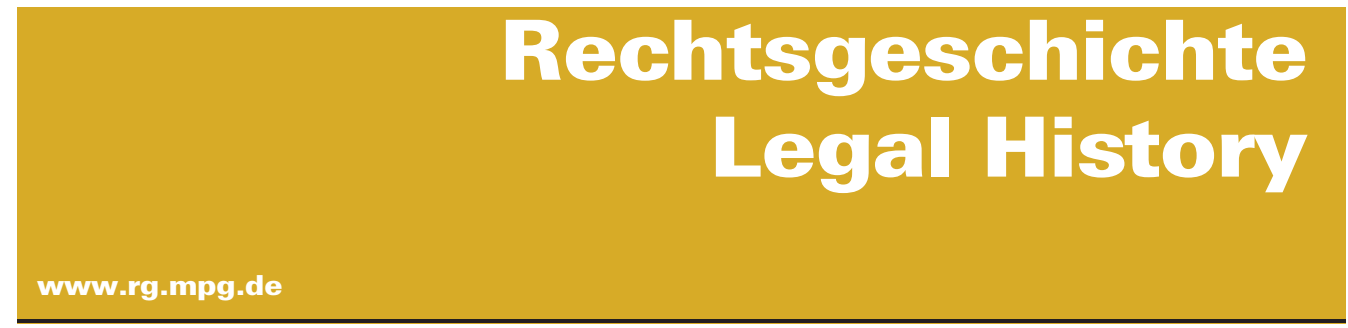

http://www.rg-rechtsgeschichte.de/rg22

$\operatorname{Rg} 222014 \quad 79-89$

Zitiervorschlag: Rechtsgeschichte - Legal History Rg 22 (2014)

http://dx.doi.org/10.12946/rg22/079-089

\title{
Heiner Lück
}

Aspects of the transfer of the Saxon-Magdeburg Law to Central and Eastern Europe 


\section{Abstract}

An important impetus for the development and dissemination of the Saxon Mirror, the most famous and influential German law book of Central Germany between 1220 and 1235 by one Eike von Repgow, was the municipal law of the town of Magdeburg, the so called Magdeburg Law. It is one of the most important German town laws of the Middle Ages. In conjunction with the Saxon Mirror with which it was closely interconnected, the Magdeburg Law reached the territories of Silesia, Poland, the lands belonging to the Teutonic Order, the Baltic countries (especially Lithuania), Ukraine, Bohemia, Moravia, Slovakia and Hungary. The peculiar symbiosis between Saxon Mirror and Magdeburg Law on the way to Eastern Europe has been expressed in the source texts (ius Teutonicum, ius Maideburgense and ius Saxonum in the early originally carried the same content). Ius Maideburgense (Magdeburg Law) has reached the foremost position as a broad term, which encompassed the Saxon territorial law as well as the Magdeburg town law, and, quite frequently, also the German Law (ius Teutonicum) in general. Modern scholarship recognizes this terminological overlapping and interrelatedness through the notion of SaxonMagdeburg Law. In a very complex process of legal transfer, the Saxon-Magdeburg Law became a fundamental source of the legal systems in several Eastern European states during the late Middle Ages and the early modern period. In this sense the Saxon-Magdeburg Law contributed to the groundwork of the development of law in Europe. Milestones achieved in the process included the formal concession of Magdeburg Law to the capitals Krakow (Poland), Kiev (Ukraine), Minsk (Belarus), Vilnius (Lithuania) and other towns by kings and princes between the $13^{\text {th }}$ and $15^{\text {th }}$ centuries. 


\section{Heiner Lück \\ Aspects of the transfer of the Saxon-Magdeburg Law to Central and Eastern Europe*}

For decades, scholars have been preoccupied with the spread of two important historical legal documents from the German Middle Ages to regions in Central and Eastern Europe: ${ }^{1}$ Sachsenspiegel (lit. "Saxon Mirror «), ${ }^{2}$ a legal code of the German Middle Ages which had an enduring effect on German law for many centuries and Magdeburger Recht (Magdeburg Law), ${ }^{3}$ a set of town privileges developed under the reign of Otto I. (936973) and his successors. ${ }^{4}$

The relevance of these documents today, and the curiosity they have sparked, extend far beyond the academic environs. There has been a general revival of the interest in the common origins of European statehoods and legal orders, and more so in the context of the integration of a couple of Central and Eastern European countries into the European Union in 2004, having been involved in research programmes requiring the study of historical sources on an unprecedented scale and in close cooperation with many distinguished European scholars, ${ }^{5}$ and having reflected on the popularity of these two fundamental sources of law that evolved in Central Germany (the Saxon Mirror and Magdeburg Law). ${ }^{6}$ The significance of concepts attributed to the Saxon-Magdeburg Law may vary considerably, but all these concepts concern a highly developed medieval town law which - by its very name - points to one of the metropolises of the Holy Roman Empire. ${ }^{7}$ The continued prevalence of these concepts also reflects the tendency to opt for a Europe whose scope transgresses the borders of the contemporary states - a Europe whose identity for many centuries had been defined through the use of the Latin script and by the Church. ${ }^{\mathbf{8}}$ Perhaps these historical ties - which, by the way, seem very current today - carry a certain potential for the future, especially in the context of the growing awareness of, and interest in, such issues in the economic sphere.

In four parts, this paper presents a number of arguments to support a conviction that at first glance may seem subjective. Part 1 describes the situation in the twelfth and the thirteenth centuries in the regions where Saxon Mirror evolved. Part 2 introduces Magdeburg as the so-called $»$ mother city " ${ }^{9}$ of one of the most significant European town laws. Part 3 discusses the phenomenon of the expansion of Magdeburg Law in the territory of Central and Eastern Europe, and, finally, Part 4 presents select reasons, for which even today we may consider Magdeburg Law a factor that defines the identity of many cities and towns of Central and Eastern Europe.

\section{The starting point}

The history of our civilisation in the Middle Ages and in the early modern era is in many ways linked to towns and provinces, which are today situated within the former territorial borders of the Holy Roman Empire and of other feudal states in Europe. In European law, these links undoubtedly
* Based on my former paper Lück (2007a).

1 Problems of the terms »transfer « and "reception" are discussed by LücK (2013c) 298-302. See also the maintitle of EICHLER / LüCK (2008).

2 English edition of the famous German law book by Doвоzy (1999).

3 The sources of Magdeburg Law are several law books and thousands of decisions of the Magdeburg Bench ("Schöffenstuhl«); overview on the Magdeburg law books by JoHANeK (2004); most important editions of decisions of the Magdeburg Bench by
Ebel (1983), Ebel (1989), Ebel (1995).

4 About the history of research cf. LücK (2009b).

5 There is a research project at the Saxon Academy of Sciences Leipzig "Das sächsisch-magdeburgische Recht als kulturelles Bindeglied zwischen den Rechtsordnungen Ostund Mitteleuropas«. Edited Volumes: EICHLER / LÜCK (2008); BiLY et al. (2011); GöNCZI / CARLS (2013). See also: LüCK (2008).

6 Cf. also LüCK (1998a) 7. Cf. SCHNeIDMÜLLER (2006).
7 Cf. SChNeidmüller (2006).

8 Thomas Duve also mentioned »identification « in his welcome speech yesterday (2013 Sept. $\left.2^{\text {nd }}\right)$.

9 The terms »mother city«, "parent city«, »daughter city«, »grandchild city« are deliberately used in inverted commas here, since these are modern concepts which have been constructed to describe the specificity of the "family of the cities of (German) law «.These terms do not appear in the original source texts. Cf. KroesChelL (2008) 275-278. 
cover the Saxon Mirror and the town law that first evolved in the City of Magdeburg. ${ }^{10}$ These sources of law have not only impacted on the specific legal spheres in Central, Eastern and Northern Germany, but they have also greatly influenced the legal order of many Eastern European countries. ${ }^{11}$ The Saxon Mirror, written between 1220 and 1235 in Middle Germany, ${ }^{\mathbf{1 2}}$ mainly contains regulations concerning the population of rural settlements (but it also contains legal regulations which originated in the imperial and canon law). ${ }^{\mathbf{1 3}}$

The Saxon Mirror belongs to a larger set of private [perhaps even individual] compilations of customary laws that had emerged throughout Europe in the thirteenth century, even in Germany - and subsequently recorded in the law books. ${ }^{\mathbf{1 4}}$ The Saxon Mirror is the most famous and influential of the individually compiled German treatises to be drawn up in the first half of the thirteenth century and is attributed to Eike von Repgow. ${ }^{15}$

»In the courts of Saxony, the Sachsenspiegel soon came to be treated almost as if it were an authoritative text... ${ }^{\mathbf{1 6}}$ Legend has it that the written law of the Saxons had to be an imperial legislative act. »Throughout Saxony it provided a basis for development and gave life to the law of the whole region. During the fourteenth century it was glossed ${ }^{17}$ by Johann von Buch, ${ }^{18}$ a graduate of Bologna Law School, »on a number of occasions, either in whole or in part, and supplements to it, especially in the form of manuals of court procedure, were produced.« ${ }^{19}$ It was a singular point of orientation for all the courts in Saxony, in effect, offering a counterpoint to legal particularism. Its existence and use can probably explain why Saxony was among those areas in Germany least affected by the widespread adoption of Roman law. ${ }^{20}$ The influence of Sachsenspiegel in other parts of Germany is evidence of the broader de- mand for a written law ${ }^{21}$ in a localized form, befitting the local circumstances.

The inclusion of some rules in the Saxon Mirror seems to reflect its special relationship with the City of Magdeburg. ${ }^{22}$ A number of legal norms that had been successfully implemented and proven valuable not just in the realm of trade and crafts ${ }^{23}$ but also for addressing questions concerning the maintenance of a balance of power (both inside and outside the city) had developed in Magdeburg. $^{24}$

Already in the eleventh century, some towns in Central Germany had initiated the trend that rejected the general legal order of the regimes in the surrounding areas. At a more advanced level, this trend eventually became necessary to differentiate and separate the still binding general civil code (Landrecht or land law) from town laws that had evolved in connection with the development of the privileged position of towns and the establishment of municipal legal norms. Contrary to the land law (Landrecht) and feudal law (Lehnrecht), the town law emerged as a relatively independent set of sources of law as late as in the mid-thirteenth century. Generally, but especially in regard to personal liberty issues, the regulations under this kind of law differed significantly from those in land law.

The crucial difference between a city or town and the surrounding areas was of a legal nature, ${ }^{25}$ and this mostly pertained to the two basic aspects that regulated the coexistence of the town inhabitants. On the one hand, at the base of municipal social relations lay the special legal regulations that did not use the dependency relations, which were a typical feature of land law. ${ }^{26}$ On the other hand, the inhabitants of towns (the burghers) came under the rule of a specific legal system, wherein all the burghers ${ }^{27}$ were bound by an oath and
10 Of particular significance in this context is the international conference organized as a joint effort of Polish and German legal historians (Kraków 1977). Cf. WilloweIt / SCHICH (1980).

11 SChubart-Fikentscher (1942); LIEBERWIRTH (1986); LÜCK (2013a).

12 Cf. the genesis of the Saxon Mirror: LÜCK (2013a) 13 seqq.; LANDAU (2005); concerning especially the feudal law $\left(2^{\text {nd }}\right.$ part of the Saxon Mirror) cf. LücK (2013b).
13 Cf. LÜCK (2006); LüCK (2007b).

14 LücK (2014).

15 Robinson et al. (1994) 186. See also LIEBERWIRTH (2008).

16 Robinson et al. (1994) 186.

17 Robinson et al. (1994) 186; see also KanNowsKi (2006).

18 LüCK (2012a).

19 Edition of the famous "Buch'sche Glosse« by Kaufmann (2002).

20 Cf. LÜCK (2013d).

21 Robinson et al. (1994) 186.

22 Cf. LÜCK (2005).
23 For a more extensive discussion on this subject see: PuHLE (2005).

24 Cf. LüCK (1996); Puhle (2005).

25 Cf. Cordes (2003).

26 See also: Dilcher (1999) 600-682.

27 For further details about this term see: Kroeschell/Cordes (2008). 
subject to the decisions of a given Council which functioned as an organ of a local self-government of the urban commune (at least that was the case from the first decades of the thirteenth century on). German towns usually followed a legal system based on privileges granted by the local rulers that could be exercised in the settlement in question (originally the privileges were often granted only to merchant settlements). At some point, the privileges (in their written form) were collected and compiled, which resulted in the creation of the so-called Handfeste - the early version of town law in the form of handwritten official documents, which had the character of solemn pledges. ${ }^{28}$ Such privileges often pertained to judicature, court proceedings and burghers' liberties, such as the right to the free use of one's land.

In Magdeburg, an important centre of trade located at the margins of lands inhabited by the Slavs, ${ }^{29}$ the customary legal norms, appropriate to the urban conditions of manufacture and trade could develop relatively early. A totally different situation developed in 1188, when Archbishop Wichmann (1152-1192) granted a special privilege to the City of Magdeburg, which entailed specific improvements to and a simplification of the court proceedings. ${ }^{30}$ The privilege freed the burghers from the perilous risks hidden in the highly formalised legal proceedings. Therefore, it assumed the existence of a specific legal order within the boundaries of the town that differed significantly from the land law used in its political environs.

At the beginning of the thirteenth century, the Polish Prince Henry I of Silesia (1202-1238) asked for a copy of Wichmann's privilege so that he could use it as a legal basis for his newly-founded town of Złotoryja (Goldberg; 1211). Over the subsequent three decades, Magdeburg Law ${ }^{31}$ had been granted to such towns as Spandau (1232), Prenzlau (1235), Guben (1235) and Szczecin (Stettin; 1237). In the course of the thirteenth century, a new legal stratum was added to these privileges - the new elements of the legal system had evolved to a great extent from the regulations worked out by the municipal institutions and the legal instructions issued by the members of the board which constituted the Bench of a given city and / or by the members of the City Council.

2 Magdeburg as the "mother city« of a significant family of cities of German town law

These legal norms targeted specific relations that functioned within the municipal sphere, often serving as the legal foundation for the newly established (or re-established) towns. These acts were performed on the basis of the appropriate privileges, as defined in the chartering document. Also the already existing, older cities and towns sometimes benefitted from privileges derived from the adoption of a variant of laws already in use at another city - this process is referred to as Bewidmung (or a formal transfer by a special charter) in the German history of law, and the City of Krakow is a perfect example thereof. The formal establishment of Krakow under Magdeburg Law (in the transplant variant of a law valid in the City of Wrocław/Breslau) is still vivid in the collective memory, even 750 years after the actual issuing of the Great Charter. ${ }^{32}$ In this process, the new legal kinship established family ties between the »daughter cities « and their »mother city «. ${ }^{33}$ From the »daughter cities « the law (or, frequently, the regional variant thereof adapted to the local conditions) was imported into other towns which, in turn, led to the formation of extensive "families of cities of German town law«, among which the most significant were the family of Magdeburg Law ${ }^{34}$ and the family of Lübeck Law. ${ }^{35}$

The family ties with the "mother city" were established not only owing to the sharing of the same variant of town law that was being passed on
28 Armgart (2012).

29 KLEINEN/SPRINGER (2005).

30 For more extensive information on that subject see: LIEBERWIRTH (1990).

31 To sources, structure, contents etc. see Buchda (1984); Ebel (1992); Ebel (2004).

32 See Muzeum Historyczne Miasta Krakowa (2007).
33 Kroeschell (2008) 275-278.

34 LüCK (2013a) 61 seqq.

35 Ebel (2009); Henn (2009); LücK (2009a). 
from town to town, but - most of all - through the common practice of asking for legal instructions and information, ${ }^{36}$ which were usually obtained either from the City Council of the "mother city" (e.g. in the case of Lübeck), or from the court of aldermen, or the Bench of the "mother city« (e. g. in the case of Magdeburg). ${ }^{37}$ It was a regular practice when the authorities of a given city or town were to interpret their own municipal law, i. e. when the local law contained legal loopholes. The City Council or the Bench of the "mother city« replied to such requests by issuing legal instructions (Polish: ortyle, from Old German Urteil). Requests for the copies of the "mother law « were also made in connection with the formal establishments of towns or the loss of the already written "daughter law« (e.g. when the entire municipal legal documentation had been destroyed in a fire).

Eventually, this kind of legal assistance was extended, as there was an urge to adjudicate certain legal cases by the court of aldermen in the "mother city«. In such cases, the City Council, or the Bench of the "mother city" prepared the verdicts, which were then merely delivered by the court of the »daughter city«. These Spruchkollegien (decisionmaking panels) were not proper courts in the strictest sense of the term and could only respond to more general requests for legal help. Such verdicts were authoritative, as boards (»higher courts ${ }^{38}$ and Benches) took on legal experts as members (without formal legal education). Within their expertise, they used the law they found in the written sources available to them, or they had encountered in the prevalent oral legal traditions. ${ }^{39}$ The legal instructions and verdicts issued by such legal experts were collected and compiled into separate volumes - such collections of legal documents should be perceived as yet another group of sources of the German town law.

The relation of the »mother city« to the »daughter cities « has been described as that of »the higher court of appeals«. The term »higher court « (Oberbof) ${ }^{40}$ in this case signifies the board consisting of aldermen (the Bench) or the City Council of the "mother city" - as these institutions possessed more extensive legal knowledge and experience than the institutions operating in the »daughter cities«. The figures of »mother cities « and »daughter cities « have been criticized by the recent discussion. ${ }^{\mathbf{4 1}}$

From the fifteenth century onward, two major phenomena of the history of German law and legal system started to impede the functioning of the municipal courts of aldermen (whose members were not legal experts or professional lawyers). The introduction of Roman Law and Canon Law made it increasingly necessary for the judicature to be based on solid, scientific foundations. There was a discrepancy between the lay judicature and the judicature based on scientific foundations, and several attempts to bridge that gap, for instance by establishing law at departments at universities that either replaced the old courts of aldermen, or coexisted with older institutions. On the other hand, some territories developed into hermetic spheres controlled by judicial systems at the head of which stood the local prince or his royal court. This hermetic approach of the rulers of a given land entailed the prohibition of making appeals at the jurisdictional boards of the higher instance that resided outside the territory of the land in question.

The Magdeburg Bench (Magdeburg Jury Court) had now to compete with the faculties of law, which by that time had been established in the nearby cities (i.e. in Frankfurt on Oder, Jena, Helmstedt, Leipzig, and Wittenberg), ${ }^{\mathbf{4 2}}$ as well as with more modern courts of aldermen (e.g. in Brandenburg, Halle, Jena, Leipzig and Wittenberg), whose position was even more privileged due to the advantageous legislation of the territorial states. Between 10 and 20 May, 1631, the imperial army of the (Roman Catholic) General Johann von Tillie destroyed the City of Magdeburg as the stronghold of the Lutheran Reformation movement (»our Lord God's pulpit«). ${ }^{43}$ The seat of the Bench and its archive were demolished. ${ }^{\mathbf{4 4}}$ Thus, the thousands of court documents as well as
36 Cf. WerkMüller (1990a); WerkMÜLler (1990b).

37 LücK (2004). See also: KISCH (1980b).

38 The use of the term "higher court" (Oberhof) in the context of the cities of the Saxon-Magdeburg legal circle is highly problematic, since the term itself does not evidently appear in the sources of Saxon-Magdeburg Law.

Rather, the sources mention "aldermen « and »court of aldermen«, or »the Bench«. Cf. WerkmüLler (1984); LüCK (2010). Further and more detailed research on this subject seems to be a necessity.

39 See also Robinson et al. (1994) 185.
40 WerkmüLleR (1984).

41 Dusil (2007) 21-40; Dilcher (1999) 628.

42 Lück (1998b) 64 seqq.

43 Cf. von Elsner (1998) 113; Kaufmann (2003).

44 Tullner (1998); LüCK (1999). 
all the entries in the registry - priceless for academic research - has forever been lost.

This rapid decline of the city did not destroy the fame and significance of the Magdeburg Bench for the development of town law in the German and Eastern European lands. Apart from the City Council of Lübeck, none of the comparable bodies of judicature has managed to achieve the impressive range of influence (both in geographical, and in temporal terms) of the Magdeburg Bench.

3 From Magdeburg to Europe: on the expansion of Magdeburg Law

Magdeburg Law, spreading together with the Saxon Mirror with which it was closely interconnected, reached the territories of Silesia, Poland, the lands belonging to the Teutonic Order, the Baltic countries, Belarus, Ukraine, Bohemia, Moravia, Slovakia and Hungary. ${ }^{45}$ The peculiar symbiosis into which the Saxon Mirror entered with Magdeburg Law on the way to Eastern Europe ${ }^{46}$ has been expressed in the source texts (note that in the early texts, the terms ius Teutonicum, ius Maideburgense and ius Saxonum originally carried the same content). Among these, the term ius Maideburgense (Magdeburg Law) has reached the foremost position as a broad term that encompassed the Saxon land law as well as the Magdeburg town law, and, quite frequently, also the German Law (ius Teutonicum) in general. Hence, modern science recognizes this terminological overlapping and interrelatedness through the notion of »Saxon-Magdeburg Law."

According to the early legal data obtained from the Cities of Magdeburg and Halle, the Polish Duchy of Silesia was an important intermediary in the transmission of the Saxon-Magdeburg Law in Eastern Europe. Already in the thirteenth century, a number of cities and towns, such as: Złotoryja / Goldberg (1211), Wrocław / Breslau (before 1241), Środa Śląska / Neumarkt in Silesia (1235), ${ }^{47}$ Głogów/Glogau (1263) and a few others, were formally established under Magdeburg Law.
As the seats of »higher courts", Wrocław and Środa Śląska continued to popularize Magdeburg Law as legal instructions.

From Silesia, Magdeburg town law and the Saxon Mirror came to Poland. The City of Kraków was formally established under the Wrocław regional variant of Magdeburg Law in $1257^{48}$ (not only did the city receive a new law, but it also had been practically re-founded and re-built). From Kraków, the Saxon Mirror and Magdeburg Law spread in the eastern direction and approached Red Rus' and in the northern direction, towards the Wielkopolska region. In 1253 the City of Pozńan was formally established under Magdeburg Law and also became the seat of a "higher court" for the towns that used Magdeburg Law in Wielkopolska.

Especially in order to cater to the needs of the cities and towns of Magdeburg Law in the Małopolska region, in 1356 Polish King, Casimir III the Great (1333-1370) established a special »higher court" - ius supremum Magdeburgensis castri Cracoviensis - at Wawel Castle in Kraków (a collection of court rulings published by Ludwik Łysiak and Karin Nehlsen-von Stryk). ${ }^{49}$ Apart from that, Casimir the Great spared no pains to expand the range of Magdeburg Law to the newly-annexed eastern territories of Volhynia, Halych, and Podolia (today parts of the Ukraine) by granting numerous privileges to the settlements situated in those areas. All in all, in Małopolska (Little Poland) and Halych, approximately 650 towns and villages had been formally established under German law, whereas in Wielkopolska (Major Poland) the number of towns and villages to have been formally established under that law stood at about 150 .

In the areas that came under the Teutonic Order, the Saxon-Magdeburg Law was realized mostly through grants of the Kulm/Chełmno privilege (Kulmer Handfeste). ${ }^{50}$ In 1233, the Kulm privilege was granted to the Cities of Torun (Thorn) and Chełmno (Kulm) by the grand master of the Teutonic Order. ${ }^{51}$ Both developed into metropolises of German Law in those lands and - as »higher courts« - contributed to the further expansion of
45 For the following data see Lück (2013a) 61 seqq.; Lück (2013c).

46 About the several ways of transfer see LüCK (2013c) 293-302.

47 See also: Kannowski / Dusil (2003).
48 Cf. LüCK (2009c) 27-28.

49 Łysiak/NeHLSEN-von STRYK (1995/ 1997).

50 Cf. a selection from the exentsive literature on that subject: JANICKA
(2013); KISCH (1978); RogaČEVSKIJ

(2002), ZIELIŃSKA-MELKOWSKA

(1986), ZDRóJKOWSKI (1988).

51 Cf. LüCK (2009c) 23-27. 
the Saxon-Magdeburg Law; what is more, both in the City of Torun and in the City of Chełmno more German Law books were written so that by the end of the fourteenth century, Chełmno produced a book of law based on the MagdeburgBreslauer systematisches Schöfenrecht, the rulings of the Magdeburg Bench and the Saxon Mirror. The Codex - known as Alte Kulm - spread to the lands of the Teutonic Order as well as to Poland and Ukraine. Many manuscripts cited rulings extracted from the books of Saxon law. It is very likely that between 1386 and 1402, in the City of Toruń, a book entitled Magdeburger Fragen (lit. Questions of Magdeburg Law) was written on the basis of Alte $K u l m$, as well as the legal sources from Kraków and Toruń. $^{52}$

In Lithuania, such cities as Vilnius (1387), Kaunas $(1408)$ and Trakai (late $14^{\text {th }}$ or early $15^{\text {th }}$ century) were formally established under the Magdeburg Law; the law continued to spread, and finally reached Belarus where its influence proved to be most spectacular in the legal organization of Minsk (1499).

A host of entirely new opportunities for the spread of the sources of law emerged with the invention of print. Already in 1506, the Royal Polish Chancellor Jan Łaski ${ }^{53}$ published the Latin version of the Saxon Mirror and the Magdeburg Weichbild, along with several other native (Polish) sources of law. ${ }^{54}$ In 1535, a Kraków municipal scribe, Nikolaus Jaskier, ${ }^{55}$ published glossed editions of the Latin versions of Saxon Mirror and Weichbild. ${ }^{56}$ Among other things, the publication of these works in the process of popularizing the Saxon-Magdeburg Law in the Grand Duchy of Lithuania had made the City of Kraków extremely influential. Finally, in 1581, the great Syndic of Lviv, Paweł Szczerbicz, translated Weichbild into Polish; ${ }^{57}$ it was in the same year that the Saxon Mirror had for the first time been published in an alphabetical order. ${ }^{58}$ In 1558 a distinguished
Polish scholar in the field of law - Bartłomiej Groicki $^{59}$ - published Artykuty prawa majdeburskiego, ktore zowia Speculum Saxonum (lit. Articles of Magdeburg Law known as the Saxon Mirror). ${ }^{60}$ It was also Groicki who wrote the collection entitled Porzadek sadów $i$ spraw miejskich prawa majdeburskiego $w$ Koronie Polskiej (lit: System of courts and municipal matters of Magdeburg Law under the Polish Crown), which was later to play a significant role in Slovakia and, most of all, in Ukraine. The chartering of Lviv (1356) ${ }^{\mathbf{6 1}}$ and Kiev (c. 1497/ 1499) ${ }^{62}$ and the formal establishment of these cities under Magdeburg Law were of great importance, too. ${ }^{63}$ Apart from the privileges granted to cities and towns, based on Magdeburg Law, another noteworthy group of sources in Ukraine were the so-called Sammlungen des Magdeburger Rechts (Collections of Magdeburg Rights). At that time, the Magdeburg privilege granted to the City of Kiev, Saxon-Magdeburg Law had reached the eastern borders of its territorial range (on the River Dnieper). In this context, the massive project of the codification of law was of exceptional importance. It had been prepared for Ukraine in 1743 - Prawa po kotorym suditsja malorossijskij narod (i.e. Laws of justice of the Ukranian people) - and drew heavily on the Saxon-Magdeburg sources of law. ${ }^{\mathbf{6 4}}$ Ukraine was also where Saxon-Magdeburg Law had been evidently maintained for the longest time: it only lost its primary importance when the Great-Russian collection of legal acts - the Swod sakonow Rossijskoj Imperij (lit. A collection of laws of the Russian Empire) - was introduced in 1840 in the Left-Bank Ukraine, or in 1842, in the Right-Bank Ukraine. In fact, Ukrainian law had undergone a high level of Russification in the eighteenth century before that collection of legal acts could be published.

The importance of Saxon-Magdeburg Law for the development of Ukraine ${ }^{65}$ is clearly visible even today, especially in Kiev. There is a monument
52 Cf. Lortz (2013).

53 See also GulczyŃsKi (2014).

54 ŁASKI (1506); cf. LÜCK (2013a) 78, 80; BiLY et al. (2011) 103-104.

55 See also Lück (2012b).

56 JaSkier (1535a), (1535b); Bily et al. (2011) 104-105; RYMASZEWSKI (1985).

57 SzCZERbicz (1581a); Bily et al. (2011), 105-106.
58 Szczerbicz (1581b); Bily et al. (2011) 105-106.

59 See also Janicka (2012).

60 See LücK (2013a), 78, 80; Bily et al. (2011) 108-109.

61 Cf. LücK (2009c) 28-30. New edition of the Lviv privileges by KaPRAL' (1998).

62 Cf. the new edition of the Kiev privileges by Bilous (2013).
63 Cf. von Werdt (2006) 204 seqq.

64 Cf. the modern edition of that text: Mironenko et al. (1997).

65 Goschко (2002); KozubskaAndrusiv (2007); Bilous (2008); Kobyletskij (2008). 
commemorating the membership of the City of Kiev in the Magdeburg family of the cities of German Law (the monument was erected on the bank of the River Dnieper in 1802, and the fact that we can still admire it today demonstrates that the people of Kiev must still be proud of the old privileges once granted to their city. ${ }^{\mathbf{6 6}}$

\section{Magdeburg Law as a defining factor of identity}

Before we ask if the Magdeburg Law had any impact on the identity of cities and towns, we first need to identify factors that play a significant role in the evolution of cities and towns. The factors defining the identity of cities evolved parallel to the development of cities and the formation of their internal organization in the Middle Ages. The external elements we should list here include: market square, town hall, the building of the municipal court or the seat of the Bench, city walls, municipal seal, the city's coat of arms, specific municipal books, precious privileges which had been granted to the city, as well as a statue of a knight in armour (the so-called "Roland «) or another symbolic figure of that kind, and, of course, the city's main church. All of these elements have developed a specific external form due to their links with Magdeburg Law, and all of them, collectively considered, represent a specific type of a municipal liberty. The liberty in question was also in some way rooted in the Magdeburg Law that contained a set of norms regulating the co-existence of political and social groups. These common features of the family of cities functioning under Magdeburg Law have maintained their power until the present day, which can be clearly demonstrated on the basis of the following observations.

Firstly, a number of events and conferences could be presented here, including the international conference in Vilnius (Lithuania) organized in 2004 to commemorate the $475^{\text {th }}$ anniversary of the First Lithuanian Statute (1529), or an interna- tional conference in Kiev on the $500^{\text {th }}$ anniversary of the Magdeburg-Law-privilege for the Ukrainian capital (1999). ${ }^{67}$ Moreover, the literature and sources recently published in Poland, ${ }^{68}$ Hungary, ${ }^{69}$ Belarus ${ }^{70}$ and in the Baltic states ${ }^{71}$ demonstrates the force of Saxon-Magdeburg Law as a vital subject for further research.

Secondly, the Magdeburg municipal system of self-government must have been of huge importance in the Middle Ages. The system was based on the balance of forces between the ruler of the city and the city itself on the one hand, and the various organs operating within the internal structure of the city on the other. An additional element was the privileged position of women in the regulations concerning inheritance jurisprudence. The trust put in the law to guarantee a stable way of preserving that state should also be added to that list. Therefore, we may venture to say that, in a certain sense, there is continuity between that early approach to the law and our contemporary understanding thereof.

Thirdly, many cities and towns in Eastern Europe continue to remind us about the fact that they used to be linked by a common system of town law. No matter how different all the specific legal cases of these cities might in fact have been, they used to belong to the same family functioning under the common trademark of "Magdeburg Law « - and indeed, they still belong to that family today. In this case, it is not the idiosyncratic notions associated in all of the specific cases with the term »Magdeburg Law« that matters.

Fourthly, in the context of the abovementioned issues, the Saxon Academy of Sciences in Leipzig has realized a huge research project which concentrated on the systematic research on Saxon-Magdeburg Law as a cultural link that bridges the gap between the legal orders of Eastern and Central Europe in a global world and may reside within a system of European normativity with roots in the Middle Ages.
66 Cf. LücK (1990).

67 AndrijKo et al. (2000).

68 RyMASZewSKI (1975); RyMASZEWSKI

(1985); RyMASZewSKI (1993); JANICKA (1992); KaMiŃSKa (1990); MÜHLE (2011).
69 There is a Hungarian translation of the Saxon Mirror: Blazovich / Sсhмidt (2005).

70 Keller (2005); Keller (2012).

71 Especially the issues by JoLANTA KARPAVIČIENÉ about the Magdeburg
Law in Lithuania: KARPAVIČIENE் (2005), (2008), (2009). 


\section{Bibliography}

- Andrijko, W.I., W.W. Komow, N.O. Bilous (eds.) (2000), Samowrjaduwannja w Kiewi: istorija ta sučasnist. Materiali mishnarodnoj konferenzij, priswjačenoj 500-riččju nadannja Kiewu magdeburskogo prawa. Kijw, 26-27 listopada 1999 roku. Deutsch-ukrainische Konferenz anläßlich des 500-jährigen Jubiläums der Verleihung des Magdeburger Rechts an die Stadt Kiew, Kiew

- Armgart, Martin (2012), Handfeste, in: ${ }^{2}$ HRG 2, 735-736

- Bader, Karl Siegfried, Gerhard Dilcher (1999), Deutsche Rechtsgeschichte. Land und Stadt - Bürger und Bauer im Alten Europa, Berlin

- Bilous, Natalja (2008), Kiew. Naprikinzi XV - y perschij polowini XVII stolittja. Miska wlada i samowrjaduwannja, Kiew

- Bilous, Natalja (ed.) (2013), Priwilej Kiewa kintja XV - seredini XVII st. Doslidshennja, Teksti, Kiew

- Bily, Inge, Wieland Carls, Katalin Gönczi (2011), Sächsisch-magdeburgisches Recht in Polen. Untersuchungen zur Geschichte des Rechts und seiner Sprache, Berlin

- Blazovich, László, József Schmidt (eds.) (2005), Eike von Repgow. A Szász tükör, Szeged

- Buchda, Gerhard (1984), Magdeburger Recht, in: HRG 3, 134-138

- Cordes, Albrecht (2003), »Burger und Baur scheydet nichts dann die Maur«. Dörfer, Städte und Gemeindetypen eigener Art, in: Cordes et al. (2003) 201-214

- Cordes, Albrecht, Joachim Rückert, Reiner Schulze (eds.) (2003), Stadt - Gemeinde - Genossenschaft. Festschrift für Gerhard Dilcher zum 70. Geburtstag, Berlin

- Dilcher, Gerhard (1999), Die Rechtsgeschichte der Stadt, in: Bader / Dilcher (1999) 251-827

- Dobozy, Maria (1999), The Saxon Mirror. A Sachsenspiegel of the Fourteenth Century. Translated by Maria Dobozy, University of Pennsylvania Press, Philadelphia

- Dusil, Stephan (2007), Die Soester Stadtrechtsfamilie. Mittelalterliche Quellen und neuzeitliche Historiographie, Köln

- Ebel, Friedrich (1983), Magdeburger Recht, Vol. I: Die Rechtssprüche für Niedersachsen, Köln

- Ebel, Friedrich (1989), Magdeburger Recht, Vol. II: Die Rechtsmitteilungen und Rechtssprüche für Breslau, part 1: Die Quellen von 1261 und 1452, Köln

- Ebel, Friedrich (1992), Magdeburger Recht, in: Puhle (1992) 42-54

- Ebel, Friedrich (1995), Magdeburger Recht, Vol. II: Die Rechtsmitteilungen und Rechtssprüche für Breslau, part 2: Die Quellen von 1453 bis zum Ende des 16. Jahrhunderts, Köln

- Ebel, Friedrich (2004), Des spreke wy vor eyn recht ... Versuch über das Recht der Magdeburger Schöppen, in: FiJal et al. (2004) 423-511

- Ebel, Friedrich (2009), Rechtsentstehung und Rechtstransfer im Spiegel der Überlieferung (Magdeburger und Lübecker Recht), in: LücK et al. (2009) 37-47

- Eichler, Ernst, Heiner Lück (eds.) (2008), Rechts- und Sprachtransfer in Mittel- und Osteuropa. Sachsenspiegel und Magdeburger Recht. Internationale und interdisziplinäre Konferenz in Leipzig vom 31. Oktober bis 2. November 2003, Berlin

- Elsner, Tobias von (1998), »Herrgotts Kanzlei« - Magdeburg in der Zeit der Glaubenskämpfe 1524 bis 1617, in: Puhle (1998) 114-164

- Fijal, Andreas, Hans-Jörg Leuchte, Hans-Jochen Schiewer (eds.) (2004), Friedrich Ebel. Unseren fruntlichen grus zuvor. Deutsches Recht des Mittelalters im mittel- und osteuropäischen Raum. Kleine Schriften, Köln

- Gönczi, Katalin, Wieland Carls (2013), Sächsisch-magdeburgisches Recht in Ungarn und Rumänien. Autonomie und Rechtstransfer im Donau- und Karpatenraum, Berlin

- Goschкo, Tetjana (2002), Narissi s istorii Magdeburskogo prawa w Ukraini XVI-počatok XVII st., Lviv

- Grossbölting, Thomas, Roswitha Willenius (eds.) (2009), Landesherrschaft - Region - Identität. Der Mittelelberaum im historischen Wandel. Festschrift für Prof. Dr. Mathias Tullner, Halle (Saale)

- Gulczyński, Andrzej (2014), Łaski, Jan (1455-1531), in: ${ }^{2}$ HRG, fasc. 19, 646-647

- Henn, Volker (2009), Lübisches Recht in den Auslandsniederlassungen der Hanse, in: Lück et al. (2009) 49-65

- HRG (1971-1998): Erler, Adalbert, Ekkehard Kaufmann (eds.), Handwörterbuch zur deutschen Rechtsgeschichte, Vol. 1-5, Berlin

- ${ }^{2}$ HrG (2008 seqq.): Cordes, Albrecht, Hans-Peter Haferkamp, Heiner Lück, Dieter Werkmüller (eds.), Handwörterbuch zur deutschen Rechtsgeschichte, $2^{\text {nd }}$ ed., Vol. 1 (2008), Vol. 2 (2012), fasc. 17-18 (2013), fasc. 19 (2014), Berlin

- Huschner, Wolfgang, Enno Bünz, Christian Lübke (eds.) (2013), Italien - Mitteldeutschland - Polen. Geschichte und Kultur im europäischen Kontext vom 10. bis zum 18. Jahrhundert, Leipzig

- Jäger, Friedrich (ed.) (2010), Enzyklopädie der Neuzeit, Vol. 11, Stuttgart

- Janicka, Danuta (1992), Prawo karne w trzech rewizjach prawa chełmińskiego z XVI wieku, Toruń

- Janicka, Danuta (2012), Groicki, Bartolomaeus (um 1534-1605), in: ${ }^{2}$ HRG 2, 561-562

- Janicka, Danuta (2013), Kulmer Handfeste, in: ${ }^{2}$ HRG, fasc. 18, 307-309

- Jaskier, Nikolaus (1535a), Iuris provnincialis quod Speculum Saxonum vulgo nuncupatur libri tres opera vigilanti in correctiorem redacti materiam, adiunctis simul glossis, aliisque addictionibus noviter recollectis pro interpretatione textus magis necessariis, Cracoviae

- Jaskier, Nikolaus (1535b), Iuris Municipalis Maidenburgensis liber vulgo Weichbild nuncupatus ex vetustissimis exemplaribus vigilanti opera latinitati datus, summaque cum diligentia recognitus, adiunctis simul glossis et textus interpretationibus ad id necessariis, Cracoviae

- Johanek, Peter (2004), Magdeburger Rechtsbücher, in: Ruh et al. (2004) 945-953

- Kamińska, Krystyna (1990), Lokacje miast na prawe magdeburskim na ziemiach polskich do 1370 r., Toruń 
- Kannowski, Bernd (2006), The Sachsenspiegel and Its Gloss in Context of European Legal History as Exemplified by Criminal Procedere, in: Vogt / MünSTER-SwENDSEN (2006) 193-206

- Kannowski, Bernd, Stephan Dusil (2003), Der Hallensische Schöffenbrief für Neumarkt vor 1235 und der Sachsenspiegel, in: ZRG GA 120, 61-90

- Kapral', Miron (ed.) (1998), Priwilej mista L'wowa (XIV-XVIII st.), L'viv

- Karpavičiené, Jolanta (2005), Moteris Vilniuje ir Kaune XVI a. pirmojoje puseje. Gyvenimo sumiestinimo Lietuvoje atodangos, Vilnius

- Karpavičiené, Jolanta (2008), Das sächsisch-magdeburgische Recht in Litauen: Forschungsstand, Forschungsfelder und Perspektiven, in: EICHLER/LüCK (2008) 75-101

- KarpavičienĖ, Jolanta (2009), Das sächsisch-magdeburgische Recht in den Kleinstädten Litauens, in: LücK et al. (2009) 83-116

- Kaufmann, Frank-Michael (ed.) (2002), Glossen zum Sachsenspiegel-Landrecht, Buch'sche Glosse, 3 Vol., Hannover

- Kaufmann, Thomas (2003), Das Ende der Reformation. Magdeburgs »Herrgotts Kanzlei« (1548-1551/2), Tübingen

- Keller, Wolga B. (2005), Saksonskae Ljustra. Pomnik pravavoj dumki Germanii XIII st., Minsk

- Keller, Wolga B. (2012), Srednewekowoe nemezkoe prawo na semljach zentralnoj i wostočnoj Ewropy w XIII-XVIII wekach, Minsk

- Kisch, Guido (1978), Die Kulmer Handfeste. Text, rechtshistorische und textkritische Untersuchungen nebst Studien zur Kulmer Handfeste, dem Elbinger Privilegium von 1246 und einem Beitrag zur Geschichte des Begriffes »ius teutonicum«, "Deutsches Recht« im Deutschordensgebiet, Sigmaringen

- Kisch, Guido (ed.) (1980a), Forschungen zur Rechts- und Sozialgeschichte des Mittelalters. Mit einem Verzeichnis der Schriften von Guido Kisch zur mittelalterlichen Rechtsgeschichte, Sigmaringen

- Kisch, Guido (1980b), Magdeburg Jury Court Decisions as Sources of Jewry-Law. A Study in Source History, in: Kisch (1980a) $122-129$

- Kleinen, Michael, Matthias Springer (2005), Vom Grenzhandelsplatz zur Stadt - Magdeburg zwischen 805 und 1251, in: Puhle / Petsch (2005) 43-74

- KobyletskiJ, Mikola (2008), Magdeburske prawo w Ukraini (XIV - perscha polowina XIX st.). Istoriko-prawowe doslidschennja, Lviv

- Kozubska-Andrusiv, Olga (2007), Ius Teutonicum Magdeburgense in Ruthenian Privileges in the Fourteenth and the Fifteenth Centuries, in: The Historical Museum of the City of Kraków (2007) 154-158

- Kroeschell, Karl (2008), Deutsche Rechtsgeschichte, Bd. 1: Bis 1250, $13^{\text {th }}$ ed., Köln

- Kroeschell, Karl, Albrecht Cordes (2008), Bürger, in: ${ }^{2}$ HrG 1, 738-747

- Landau, Peter (2005), Der Entstehungsort des Sachsenspiegels. Eike von Repgow, Altzelle und die anglo-normannische Kanonistik, in: Deutsches Archiv für Erforschung des Mittelalters 61, 73-101

- Łaski, Jan (1506), Commune inclyti Regni Poloniae privilegium constitutionum et indultum publicitus decretorum approbatorumque, Cracoviae

- Lieberwirth, Rolf (1986), Das sächsisch-magdeburgische Recht als Quelle osteuropäischer Rechtsordnungen, Berlin

- Lieberwirth, Rolf (1990), Das Privileg des Erzbischofs Wichmann und das Magdeburger Recht, Berlin

- Lieberwirth, Rolf (2008), Eike von Repgow (um 1180 - nach 1233), in: ${ }^{2}$ HRG 1, 1288-1292

- Lortz, Katarzyna (2013): Das Magdeburger Recht in den »Magdeburger Fragen«, Diss. iur. Halle-Wittenberg

- Lück, Heiner (1990), Das Denkmal des Magdeburger Rechts in Kiew, in: Forschungen zur Rechtsarchäologie und Rechtlichen Volkskunde 12, 109-119

- Lück, Heiner (1996), Der Magdeburger Schöffenstuhl als Teil der Magdeburger Stadtverfassung, in: PuHLE (1996) 138-151

- Lück, Heiner (1998a), Sachsenspiegel und Magdeburger Recht. Europäische Dimensionen zweier mitteldeutscher Rechtsquellen, Hamburg

- Lück, Heiner (1998b), Die Spruchtätigkeit der Wittenberger Juristenfakultät. Organisation - Verfahren - Ausstrahlung, Köln

- Lück, Heiner (1999), »Der Deutsche kommt also in kein Neuland ...« Das Institut zur Erforschung des Magdeburger Stadtrechts (1940-1945), in: Lück/Freitag (1999) 125-145

- Lück, Heiner (2004), Eine Rechtsmetropole des Mittelalters und der frühen Neuzeit, in: Magdeburg - Porträt einer Stadt, $2^{\text {nd }}$ ed., Halle an der Saale, 271-286

- Lück, Heiner (2005), Magdeburg, Eike von Repgow und der Sachsenspiegel, in: Puhle/Petsch (2005) 155-172

- Lück, Heiner (2006), Der Sachsenspiegel und das Kaiserrecht. Vom universalen Geltungsanspruch eines partikularen Rechtsbuches, in: Puhle/ Hasse (2006) 263-273

- Lück, Heiner (2007a), Magdeburg Law as a Defining Factor of the Identity of the European Family of Cities, in: The Historical Museum of the City of Krákow (2007) 136-146

- Lück, Heiner (2007b), Römisches und kanonisches Recht in der Dresdner Bilderhandschrift des Sachsenspiegels. Ausgewählte Beispiele, in: Steppan / Gebhardt (2007) 235-249

- Lück, Heiner (2008), Einführung: Das sächsisch-magdeburgische Recht als kulturelles Bindeglied zwischen den Rechtsordnungen Ost- und Mitteleuropas, in: EICHLER/Lück (2008) 1-28

- Lück, Heiner (2009a), Zur Gerichtsverfassung in den Mutterstädten des Magdeburger und Lübecker Rechts, in: Lück et al. (2009) 163-181

- Lück, Heiner (2009b), »Deutsches Recht im Osten« - Strukturen, Kontexte und Wirkungen eines sensiblen Forschungsthemas (19. Jh. bis 1990), in: ZRG GA 126, 175-206

- Lück, Heiner (2009c), Anfänge der Stadtverfassung nach Magdeburger Recht in Ostmitteleuropa: Kulm (1233), Thorn (1233), Krakau (1257), Lemberg (1356), in: GrossBölting/Willenius (2009) 18-37

- Lück, Heiner (2010), Schöffenstuhl, in: JäGer (2010) 527-529

- Lück, Heiner (2012a), Johann von Buch (um 1290 - um 1356), in: ${ }^{2}$ HRG 2, 1376-1377 
- Lück, Heiner (2012b), Jaskier, Nikolaus (1504 - um 1560), in: ${ }^{2}$ HRG 2, 1355-1356

- Lück, Heiner (2013a), Über den Sachsenspiegel. Entstehung, Inhalt und Wirkung des Rechtsbuches. Mit einem Beitrag zu den Grafen von Falkenstein im Mittelalter von Joachim Schymalla, $3^{\text {rd }}$ ed., Wettin-Löbejün

- Lück, Heiner (2013b), Woher kommt das Lehnrecht des Sachsenspiegels? Überlegungen zu Genesis, Charakter und Struktur, in: SPIESS (2013) 239-268

- Lück, Heiner (2013c), Rechtstransfer und Rechtsverwandtschaft. Zum Einfluss des Magdeburger Stadtrechts im Königreich Böhmen, in: MaLỳ/Šouša (2013) 298-317

- Lück, Heiner (2013d), Sächsisches Recht contra Römisch-kanonisches Recht. Ein Sonderweg der »Rezeption der fremden Rechte«?, in: Huschner et al. (2013) 211-229

- LücK, Heiner (2014), Rechtsbücher als "private« Rechtsaufzeichnungen?, in: ZRG GA 131, 418-433

- Lück, Heiner, Werner Freitag (eds.) (1999), Historische Forschung in Sachsen-Anhalt. Ein Kolloquium anläßlich des 65. Geburtstages von Walter Zöllner, Stuttgart

- Lück, Heiner, Matthias Puhle, Andreas Ranft (eds.) (2009), Grundlagen für ein neues Europa. Das Magdeburger und Lübecker Recht in Spätmittelalter und Früher Neuzeit, Köln

- Łysiak, Ludwik, Karin Nehlsen-von Stryk (eds.) (1995), Decreta iuris supremi Magdeburgensis castri Cracoviensis. Die Rechtssprüche des Oberhofs des deutschen Rechts auf der Burg Krakau 1456-1481, Frankfurt am Main

- Łysiak, Ludwik, Karin Nehlsen-von Stryk (eds.) (1997), Decreta iuris supremi Magdeburgensis castri Cracoviensis. Die Rechtssprüche des Oberhofs des deutschen Rechts auf der Burg Krakau, Vol. 2: 1481-1511, Frankfurt am Main

- Malỳ, Karel, Jiři Šouša JR. (eds.) (2013), Městské právo ve středni Evropě. Sbornik přispěvků z mezinárodni právnické konference »Práva městská Královstvi českého« z 19.-21. záři 2011, Praha, Universzita Karlova v Praze. Nakladatelstvi Karolinum

- Mironenko, O. M. et al. (eds.) (1997), Prawa, sa jakimi suditsja malorossiskij narod 1743, Kiew

- Mühle, Eduard (ed.) (2011), Rechtsstadtgründungen im mittelalterlichen Polen, Köln

- Muzeum Historyczne Miasta Krakowa (ed.) (2007), Kraków europejskie miasto prawa magdeburskiego 1257-1791. Katalog wystawy, Kraków

- Puhle, Matthias (ed.) (1992), Erzbischof Wichmann (1152-1192) und Magdeburg im hohen Mittelalter. Stadt - Erzbistum Reich. Ausstellung ..., Magdeburger Museen

- Puhle, Matthias (ed.) (1996), Hanse - Städte - Bünde. Die sächsischen Städte zwischen Elbe und Weser um 1500. Ausstellung. Kulturhistorisches Museum Magdeburg, Magdeburg

- Puhle, Matthias (ed.) (1998), Gantz verheeret! Magdeburg und der Dreißigjährige Krieg. Beiträge zur Stadtgeschichte und Katalog zur Ausstellung des Kulturhistorischen Museums Magdeburg, Halle (Saale)

- Puhle, Matthias (2005), Magdeburg im Mittelalter. Der Weg von der Pfalz Ottos des Großen bis zur Hansestadt um 1500, Halle (Saale)

- Puhle, Matthias, Claus-Peter Hasse (eds.) (2006), Heiliges Römisches Reich Deutscher Nation 962-1806. Von Otto dem Großen bis zum Ausgang des Mittelalters ..., Dresden

- Puhle, Matthias, Peter Petsch (eds.) (2005), Magdeburg. Die Geschichte der Stadt 805-2005, Dößel (Saalkreis)

- Robinson, Olivia F., T. David Fergus, William M. Gordon (1994), European Legal History. Sources and Institutions, $2^{\text {nd }}$ ed., London

- Rogačevskij, Alexander (2002), Kulmskaja gramota - pamjatnik prawa Prussii XIII w., St. Petersburg

- Ruh, Kurt et al. (eds.) (2004), Verfasserlexikon, Die deutsche Literatur des Mittelalters, $2^{\text {nd }}$ ed., Vol. 11, Suppl., Berlin

- Rymaszewski, Zygfryd (1975), Łacińskie teksty Landrechtu Zwierciadła Saskiego w Polsce. Versio Vratislaviensis, Versio Sandomiriensis, Łaski, Wrocław

- Rymaszewski, Zygfryd (1985), Łacińskie teksty Landrechtu Zwierciadła Saskiego w Polsce. Jaskier - tekst główny i noty marginesowe, Łódź

- Rymaszewski, Zygfryd (1993), Nieznany spis prawa chełmińskiego z przełomu XIV-XV wieku, Łódź

- Schneidmüller, Bernd (2006), Magdeburg und das geträumte Reich des Mittelalters, in: Schneidmüller/Weinfurter (2006) 10-43

- Schneidmüller, Bernd, Stefan Weinfurter (eds.) (2006), Heilig - Römisch - Deutsch. Das Reich im mittelalterlichen Europa, Dresden

- Schubart-Fikentscher, Gertrud (1942), Die Verbreitung der deutschen Stadtrechte in Osteuropa, Weimar

- Spiess, Karl-Heinz (ed.) (2013), Ausbildung und Verbreitung des Lehnswesens im Reich und in Italien im 12. Jahrhundert, Ostfildern

- Steppan, Markus, Helmut Gebhardt (eds.) (2007), Zur Geschichte des Rechts. Festschrift für Gernot Kocher zum 65. Geburtstag, Graz

- Szczerbicz, Pawel (1581a), Ius Municipale to jest prawo miejskie majdeburskie nowo z łacińskiego i z niemieckogo ná polski język z pilnośćią i wiernie przełoźone, Lwów

- Szczerbicz, Pawel (1581b), Speculum Saxonum albo prawo saskie i majdeburskie porzadkiem obiecadła z łacińskich i niemieckich egzemplarów zebrane a ná polski język z pilnośćią i wiernie przełoźone, Lwów

- The Historical Museum of the City of Kraków (ed.) (2007), European Cities of Magdeburg Law. Tradition, Heritage, Identity. A comparative conference Kraków, October 13-15, 2006. Conference Proceedings, Kraków

- Tullner, Mathias (1998), Das Trauma Magdeburg - Die Elbestadt im Dreißigjährigen Krieg, in: Puhle (1998) 13-24

- Vogt, Helle, Mia Münster-Swendsen (eds.) (2006), Law and Learning in the Middle Ages. Proceedings of the Second Carlsberg Academy Conference on Medieval Legal History 2005, Copenhagen

- Werdt, Christophe von (2006), Stadt und Gemeindebildung in Ruthenien. Okzidentalisierung der Ukraine und Weißrusslands im Spätmittelalter und in der frühen Neuzeit, Wiesbaden 
Fokus focus

- Werkmüller, Dieter (1984), Oberhof, in: HRG 3, 1134-1146

- Werkmüller, Dieter (1990a), Rechtsmitteilung, in: HRG 4, 313-315

- Werkmüller, Dieter (1990b), Rechtsweisung, in: HRG 4, 417-419

- Willoweit, Dietmar, Winfried Schich (eds.) (1980), Studien zur Geschichte des sächsisch-magdeburgischen Rechts in Deutschland und Polen, Frankfurt a. M.

- Zdrójкowski, Zbigniew (Red.) (1988), Studia Culmensia historico-juridica czyli księga pamiątkowa 750-lecia prawa chełmińskiego, Vol. 2, Toruń

- ZielińsKa-Melkowska, Krystyna (1986), Przywilej chełmiński 1233 i 1251, Toruń 